\title{
HEAVY MINERAL COMPOSITIONS OF LAKE PLACER SANDS IN NORTHERN FINLAND
}

\author{
RISTO PIISPANEN
}

\begin{abstract}
PIISPANEN, RISTO 1981: Heavy mineral compositions of lake placer sands in northern Finland. Bull. Geol. Soc. Finland 53-1, 29-45.

The heavy mineral $\left(\mathrm{d}>2.89 \mathrm{~g} / \mathrm{cm}^{3}\right)$ composition of 33 samples of black lake shore placer sands from a number of localities in northern Finland were analysed. The heavy fraction of the sample was obtained by treatment with bromoform $(\mathrm{d}=2.89)$ or Clerici's solution of the same density. Identifications using stereo-, polarizing and ore microscopes were made separately on both the loose material and polished impregnated thin sections. A check on the identifications was performed by applying the Debye-Scherrer X-ray powder camera method for both grains picked from the loose material and grains in the thin sections. The grain-size distribution of the loose material was determined by standard sieving techniques and the amount of magnetite by removal with a magnetic separator. The results show fairly uniform grain-size $\left(\mathrm{d}_{50} \sim 0.2 \mathrm{~mm}\right)$ and marked sorting for most of the samples. Among the minerals amphiboles are by far the most significant averaging $63.9 \%$ of the non-magnetic heavy fraction. Magnetite is also abundant, especially in those samples that are poor amphiboles, averaging $6.2 \%$ of the total heavy fraction. Next in order of abundance are ilmenite, hematite, epidote, pyroxenes and garnet. The similarity of the mineral composition of many of the samples implies that the local bedrock is only rarely, and in certain special cases, reflected in their main mineral composition. The exceptions are those from localities where large areas of the bedrock have some significant characteristic such as high epidote in the basement gneiss, and garnet in granulite.

From the point of view of the bedrock geology the results indicate that some para-amphibolites intercalated with arenaceous sediments might be the result of a similar kind of sedimentary process but, on the other hand, a process which advanced no further than this would have hardly any significance in terms of the origin of the ironformations.

Risto Piispanen, Department of Geology, University of Oulu, SF90570 Oulu 57, Finland.
\end{abstract}

\section{Introduction}

There is a commonly held belief that the black stripes of sand at the water's edge on sandy lake shores are composed predominantly of magnetite. However, accurate determinations of the mineral composition of these sediments are as far as Finland is concerned lacking, although they have been studied extensively elsewhere (Allen 1948, Baker 1945 and 1962, Bayrock 1962, Beasley 1948 and 1950, Cobb 1973, Dryden and Dryden 1946, Gardner 1955, Granath 1978, Griffith 1960, Hilmy 1951, Hutton 1950, Pardee 1934, Ras 1957, Rittenhouse 1943). The present study, therefore, aims to throw light on the mineral composition of these placer deposits of Finnish lake shores in which the washing and winnowing action of the waves in the swash-backwash zone of the shore supposedly enriched certain heavy minerals at the expense of the light minerals of the primary material (Seibold 1974). In accordance with the common practice, heavy minerals are taken as those whose density exceeds that of bromoform $\left(\mathrm{d}=2.89 \mathrm{~g} / \mathrm{cm}^{3}\right)$.

Black sands (Schott 1976, p. 253) have, in many ocean beach localities, become important sites for economic mining operations. Among the most important are the ilmenite deposits at Travancore, India (Schott 1976, p. 
258) and the titanium deposits of eastern Florida (Martens 1928 and Pirkle and Yoho 1970) where the original ilmenite has altered in various ways. The deposits of monazite, which provides the major source of thorium and an important source of cerium are mined from ocean beach placer occurrences in Brazil (Hails 1976). Diamonds are important on the coasts of south-western Africa and Mozambique (Hails 1976) and gold at Nome, Alaska as well as cassiterite in western Cornwall (Hosking and Ong 1964). The deposits obviously owe their origin to the extreme high energy conditions and the long duration of the enrichment process with the simultaneous selective removal of the light minerals from the original sediment. The present study compares the mineral composition of the lake placers with the high energy process products of the ocean beaches and attempts to reveal the differences which might be expected on the basis of the energy considerations.

A knowledge of the mineral composition of modern lake shore black sands is also significant from the point of view of the bedrock geology. When applying the principles of uniformitarianism a comparison of the modern sediments with the sedimentary rocks in the bedrock is only possible if the mineral composition of the present-day sediments is known. If similar kinds of mineral compositions are found in the bedrock it would seem justifiable to assume a similar kind of origin for them. In the case of the present study this would mean an origin associated with post-glacial lake shore processes working on glacigenic sediments.

A knowledge of the mineral composition of the modern lake shore black sands is also helpful when discussing the origin of certain Precambrian ore deposits. Should the modern black sands prove to be very rich in magnetite it could indicate an origin of a similar kind for some of the Precambrian iron-for- mations. If, on the other hand, the sediments show a marked enrichment of amphiboles, other minerals being of negligible abundance, the process might explain and be applicable to the origin of certain para-amphibolites intercalated with arenaceous sediments in the bedrock.

\section{Methods and treatment of the samples}

Material was gathered from well-developed layers of lake shore black sands in a number of localities in northern Finland. The exact locations of the sampling sites are shown in Fig. 1 and listed in Table 1. The table also indicates the maximum length of free waterway in each lake as well as the general geology of the area according to Simonen (1980).

$50 \mathrm{~cm}^{3}$ of the material was scraped off from within the swash-backwash zone at the water-line. A layer approximately $2 \mathrm{~mm}$ thick was aimed at in each case.

The laboratory treatment used is shown diagrammatically in Fig. 2. Firstly, the entire sample was decanted in large beakers in order to eliminate organic material and that mineral matter which was too fine-grained to be identified as to its mineral composition by the methods subsequently employed. Only negligible amounts of material were lost in connection with the decanting. After decanting the sample was dried at $60^{\circ} \mathrm{C}$. In order to study the grain-size distribution of the material the first 16 samples were studied using standard sieving techniques (Carver 1971).

After sieving the fractions were recombined and all the samples were split into two halves, one of the halves being stored and the other being subjected to further treatment. After weighing, magnetite was removed with the aid of a magnetic separator. The non-magnetic fraction was weighed and separated with either bromoform (samples 20-39) or Clerici's 


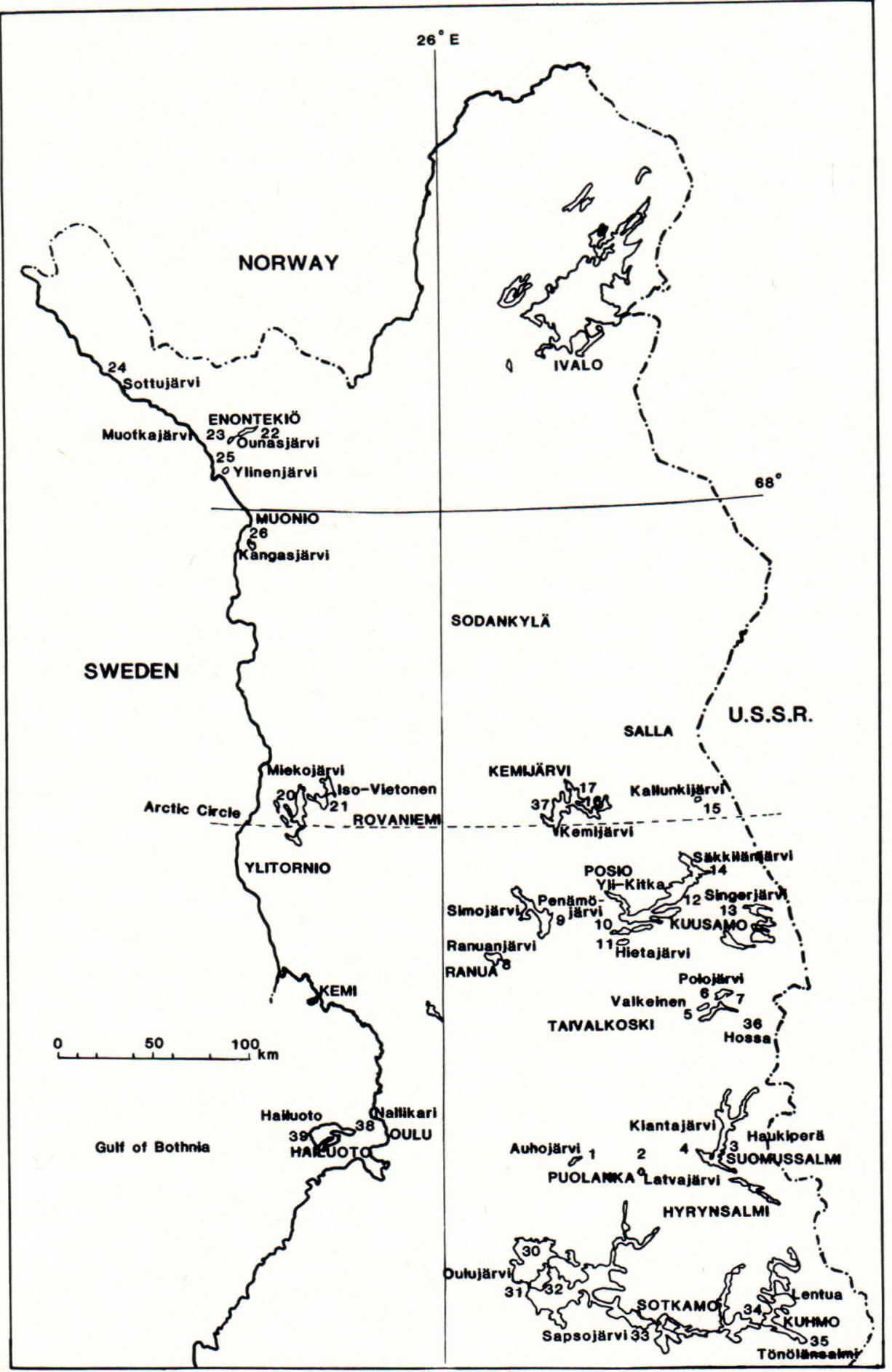

Fig. 1. Map of northern Finland showing location of sampling sites. 
Table 1. Sampling sites and the local bedrock. The general geological data is based on Simonen (1980). See Fig. 1.

\begin{tabular}{|c|c|c|c|}
\hline $\begin{array}{l}\text { Sample } \\
\text { no }\end{array}$ & Site & General geology of the area & $\begin{array}{l}\text { Maximum } \\
\text { open } \\
\text { waterway } \\
\mathrm{km}\end{array}$ \\
\hline 1 & $\begin{array}{l}\text { S.shore of Lake Auhojärvi, } \\
\text { Puolanka }\end{array}$ & $\begin{array}{l}\text { Karelian schists (quartzites, } \\
\text { greenstones etc.) }\end{array}$ & 4.0 \\
\hline 2 & $\begin{array}{l}\text { N.shore of Latvajärvi, } \\
\text { Hyrynsalmi }\end{array}$ & Karelian schists & 1.0 \\
\hline 3 & $\begin{array}{l}\text { Haukiperä, } \\
\text { Suomussalmi }\end{array}$ & $\begin{array}{l}\text { gneisses of the basement } \\
\text { complex plus greenstones } \\
\text { of the Kuhmo greenstone belt }\end{array}$ & 6.6 \\
\hline 4 & $\begin{array}{l}\text { W.shore of Kiantajärvi, } \\
1 \mathrm{~km} \mathrm{~N} \text { of Ammänsaari } \\
\text { Suomussalmi }\end{array}$ & see above & 4.0 \\
\hline 5 & $\begin{array}{l}\text { E.shore of Valkeinen, } \\
\text { Taivalkoski }\end{array}$ & $\begin{array}{l}\text { gneisses of the basement } \\
\text { complex }\end{array}$ & 2.8 \\
\hline 6 & $\begin{array}{l}\text { E.shore of Polojärvi, } \\
\text { Kuusamo }\end{array}$ & see above & 2.8 \\
\hline 7 & $\begin{array}{l}\text { SE. end of Polojärvi, } \\
\text { Kuusamo }\end{array}$ & see above & 4.0 \\
\hline 8 & $\begin{array}{l}\text { SW.shore of Ranuanjärvi, } \\
\text { Ranua }\end{array}$ & see above & 3.5 \\
\hline 9 & $\begin{array}{l}\text { N.shore of Penämöjärvi, } \\
\text { Ranua }\end{array}$ & see above & 3.0 \\
\hline 11 & $\begin{array}{l}\text { W.shore of Hietajärvi, } \\
\text { Posio }\end{array}$ & Karelian schists & 3.5 \\
\hline 12 & $\begin{array}{l}\text { E.shore of Jäkälälahti, } \\
\text { Yli-Kitka, Kuusamo }\end{array}$ & Karelian schists & 12.5 \\
\hline 13 & $\begin{array}{l}\text { N.shore of Singerjärvi, } \\
\text { Kuusamo }\end{array}$ & Karelian schists & 1.4 \\
\hline 14 & $\begin{array}{l}\text { S.shore of Säkkilänjärvi, } \\
\text { Kuusamo }\end{array}$ & Karelian schists & 2.4 \\
\hline 15 & $\begin{array}{l}\text { W.shore of Kallunkijärvi, } \\
\text { Salla }\end{array}$ & greenstones & 3.6 \\
\hline 16 & $\begin{array}{l}\text { N.shore of Äpräs, Lehtosalmi, } \\
\text { Kemijärvi }\end{array}$ & Karelian granites & 10.6 \\
\hline 17 & $\begin{array}{l}\text { W. end of Hanhiniemi, } \\
\text { Kemijärvi }\end{array}$ & Karelian granites & 22.0 \\
\hline 20 & $\begin{array}{l}\text { W.shore of Miekojärvi, } \\
\text { Muotkahieta, Ylitornio }\end{array}$ & Karelian granites & 6.0 \\
\hline 21 & $\begin{array}{l}\text { S.shore of Iso-Vietonen, } \\
\text { Ylitornio }\end{array}$ & Karelian granites & 11.6 \\
\hline 22 & $\begin{array}{l}2 \mathrm{~km} \mathrm{NE} \text { of church, } \\
\text { Ounasjärvi, Enontekiö }\end{array}$ & $\begin{array}{l}\text { Karelian schists, spilites, } \\
\text { gneisses and migmatites }\end{array}$ & 17.8 \\
\hline 23 & $\begin{array}{l}\text { N.shore of Muotkajärvi, } \\
\text { Enontekiö }\end{array}$ & see above & 6.6 \\
\hline 24 & $\begin{array}{l}\text { N.shore of Sottujärvi, } \\
\text { Muonionjoki, Enontekiö }\end{array}$ & see above & 3.4 \\
\hline
\end{tabular}


Table 1 continued

\begin{tabular}{|c|c|c|c|}
\hline 25 & $\begin{array}{l}\text { S.shore of Ylinenjärvi, } \\
\text { Muonio }\end{array}$ & granodiorites and gneisses & 3.0 \\
\hline 26 & $\begin{array}{l}\text { W.shore of Kangosjärvi, } \\
\text { Muonio }\end{array}$ & see above & 4.0 \\
\hline 30 & $\begin{array}{l}\text { W.shore of Oulujärvi, } \\
\text { Kangaskylä, campsite } \\
\text { Vaala }\end{array}$ & $\begin{array}{l}\text { gneisses of the basement } \\
\text { complex }\end{array}$ & 22.0 \\
\hline 31 & $\begin{array}{l}\text { S.shore of Alasalmi } \\
\text { Oulujärvi, Vaala }\end{array}$ & migmatites and granodiorite & 22.0 \\
\hline 32 & $\begin{array}{l}\text { SE.shore of Manamansalo, } \\
\text { Oulujärvi, Vaala }\end{array}$ & see above & 10.0 \\
\hline 33 & $\begin{array}{l}\text { N.shore of Sapsojärvi, } \\
\text { Sotkamo }\end{array}$ & $\begin{array}{l}\text { Karelian schists, mainly } \\
\text { quartzites }\end{array}$ & 11.0 \\
\hline 34 & $\begin{array}{l}\text { S.shore of Lentua, } \\
\text { Kuhmo }\end{array}$ & $\begin{array}{l}\text { gneisses of the basement } \\
\text { complex }\end{array}$ & 3.0 \\
\hline 35 & $\begin{array}{l}\text { W.shore of Tönölänsalmi, } \\
\text { Kuhmo }\end{array}$ & $\begin{array}{l}\text { gneisses of the basement } \\
\text { complex }\end{array}$ & 15.0 \\
\hline 36 & $\begin{array}{l}\text { E.shore of Hossanjärvi, } \\
\text { Suomussalmi }\end{array}$ & $\begin{array}{l}\text { gneisses of the basement } \\
\text { complex plus Archean } \\
\text { greenstones }\end{array}$ & 1.4 \\
\hline 37 & $\begin{array}{l}\text { S.shore of Lautasalmi, } \\
\text { Kemijärvi }\end{array}$ & Karelian granites & 5.6 \\
\hline 38 & Nallikari, Oulu & $\begin{array}{l}\text { migmatites of the basement } \\
\text { complex plus siltstone of the } \\
\text { Proterozoic Muhos formation }\end{array}$ & $>30$ \\
\hline 39 & Marjaniemi, Hailuoto & $\begin{array}{l}\text { siltstones of the Muhos } \\
\text { formation }\end{array}$ & $>30$ \\
\hline
\end{tabular}

solution (samples $1-17$ ) of the same density. Separation was performed in centrifuge tubes of about $50 \mathrm{~cm}^{3}$ volume. After centrifugation the heavy fraction was gathered on a filter paper in a funnel connected to vacuum pump. The heavy fraction was washed with alcohol in the case of the bromoform treatment and with hot water in the case of Clerici's solution.

Mineral identifications and the grain counts were performed using a variety of techniques. The loose material was scrutinized under a stereo-microscope and individual grains, each belonging to one of the visually differing grain groups were picked, ground and run in a Debye-Scherrer X-ray powder camera. In all, $68 \mathrm{X}$-ray camera runs were made comprising 14 identifications of hornblende and hematite, 9 of ilmenite, 5 of rutile and garnet,
4 of sphene and staurolite, 3 of epidote and two each of the following: zircon, tourmaline, apatite, pyroxene and goethite. X-ray identifications were also applied to grains removed from thin sections. The microscopic study was accomplished on polished thin sections made using the techniques described by Moreland (1968) but with some modifications. Grain counts were performed under polarizing and ore microscopes equipped with a Leitz mechanical micrometer stage. The relative amounts of the minerals were determined by counting 300 successive mineral grains. Due to the poor accuracy of the method (Carver 1971) and the difficulties involved in the identification of single grains the results are given as integer percentages, which, in the present author's opinion is in accordance with the accuracy the applied methods. 


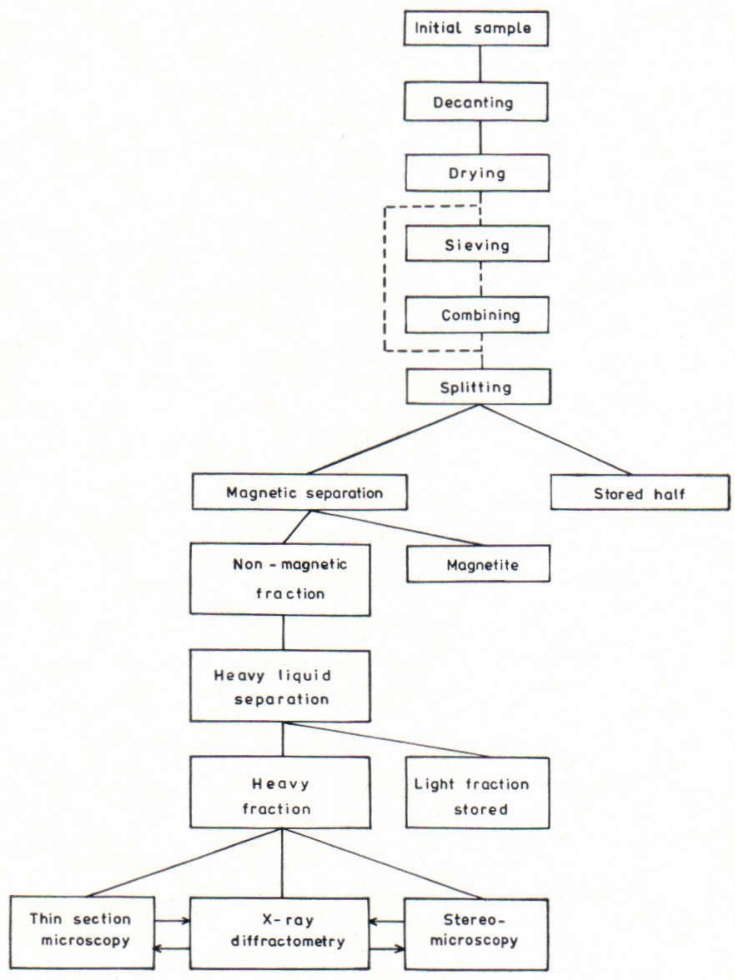

Fig. 2. Sample treatment scheme.

\section{Results}

\section{Grain-size distribution}

A determination of grain-size distribution using standard sieving techniques (e.g. Carver 1971), was made on 16 first-taken samples. Analysis of additional samples was considered unnecessary as the results of the first determinations showed such a degree of uniformity that further tests could hardly be expected to bring forth any new features. Cumulative curves are presented in Fig. 3. All the samples studied show an intersection with the 50 per cent line at or near the 0.2 $\mathrm{mm}$ bar. The exact values of the $\mathrm{d}_{50}$-line intersections are listed in Table 2. The sediments can, accordingly, be called fine sands following the 1922 Wentworth terminology (Pettijohn 1975, p. 29). A steep drop in the cumulative curves near the $0.2 \mathrm{~mm}$ bar indicates that the sediments are extremely well sorted.

\section{Total amount of heavy minerals}

The weight of magnetite and the nonmagnetic heavy mineral fraction calculated as a percentage of the total weight of each
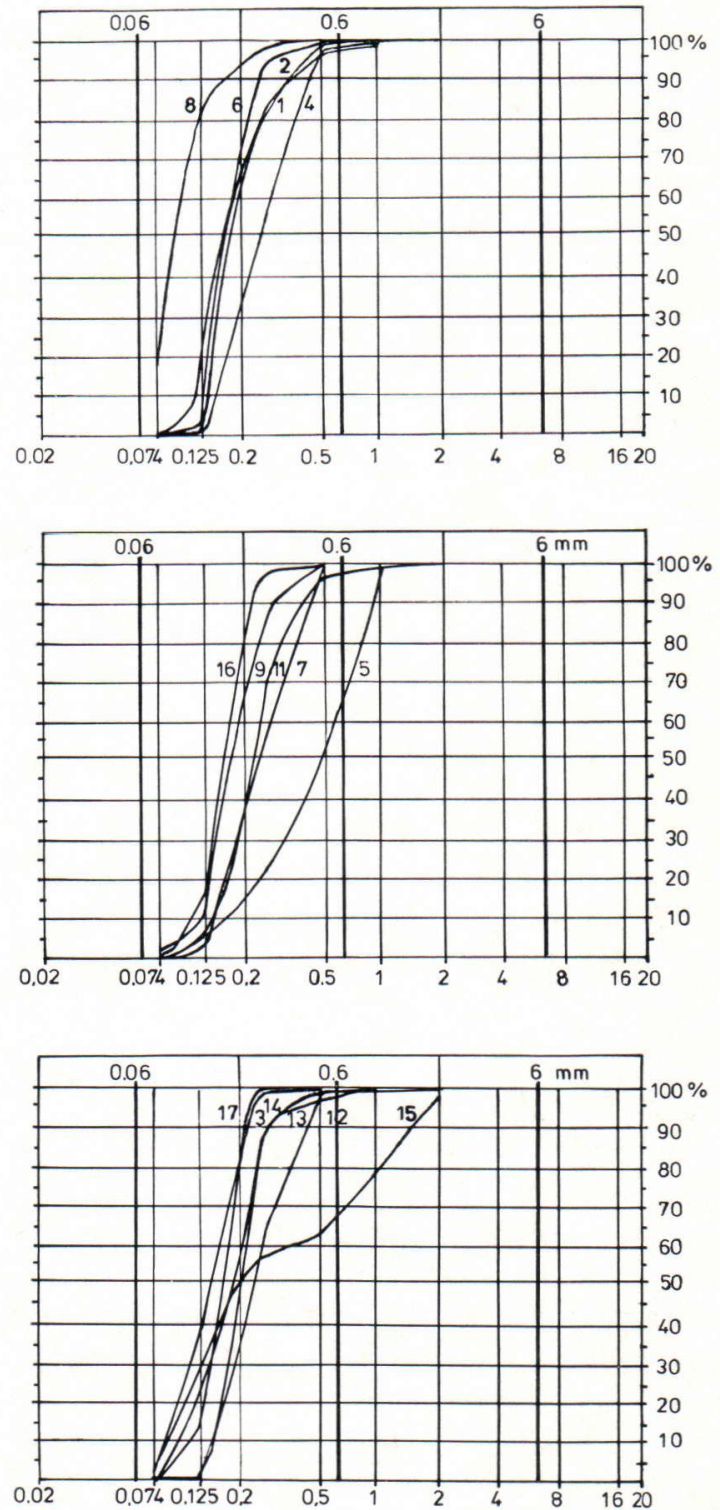

Fig. 3. Cumulative grain-size distribution curves. 
Table 2. Grain-sizes corresponding to the $\mathrm{d}_{50}$-line of the cumulative grain-size distribution curves. For sampling sites see Table 1 and Fig. 1.

\begin{tabular}{|c|c|c|c|c|c|c|c|c|c|c|}
\hline $\begin{array}{c}\text { Sample } \\
\text { no }\end{array}$ & 1 & 2 & 3 & 4 & 5 & 6 & 7 & 8 & 9 & 11 \\
\hline $\begin{array}{c}\text { grain- } \\
\text { size at } \\
\mathrm{d}_{50}(\mathrm{~mm})\end{array}$ & 0.16 & 0.16 & 0.16 & 0.40 & 0.50 & 0.16 & 0.25 & 0.10 & 0.16 & 0.25 \\
\hline $\begin{array}{c}\text { Sample } \\
\text { no }\end{array}$ & 12 & 13 & 14 & 15 & 16 & 17 & \multicolumn{4}{|c|}{ Mean/stand. dev. } \\
\hline $\begin{array}{c}\text { grain- } \\
\text { size at } \\
\mathrm{d}_{50}(\mathrm{~mm})\end{array}$ & 0.25 & 0.20 & 0.20 & 0.20 & 0.16 & 0.16 & \multicolumn{3}{|c|}{$0.22 / 0.10$} & \\
\hline
\end{tabular}

sample is listed in Table 3. The frequency distribution of the percentages with ten per cent class intervals is illustrated in Fig. 4. From both the histogram and the large standard deviation (20.57) it can be seen that the amount of heavy minerals in the samples varies considerably. The most typical values fall within the 10 to 20 per cent class while the arithmetic mean is $31.3 \%$. The lowest value recorded is 7.2 and the highest $83.4 \%$.
There are a number of possible explanations for such a strong scatter in the values. The differing values may reflect different stages of development of the placers towards maximum values in energetically differing environments. As the ages of the lakes are roughly the same in all the cases a variation in the duration of the enrichment process can be neglected and the widely different heavy mineral values can be attributed to differing

Table 3. Percentages by weight of the total amount of heavy minerals including magnetite. For sampling sites see Table 1 .

\begin{tabular}{|c|c|c|c|c|c|c|c|c|c|c|c|}
\hline $\begin{array}{c}\text { Sample } \\
\text { no }\end{array}$ & 1 & 2 & 3 & 4 & 5 & 6 & 7 & 8 & 9 & 11 & 12 \\
\hline $0 \%$ & 41.5 & 9.1 & 51.4 & 20.4 & 7.2 & 15.3 & 11.9 & 45.2 & 21.4 & 24.4 & 11.4 \\
\hline $\begin{array}{c}\text { Sample } \\
\text { no }\end{array}$ & 13 & 14 & 15 & 16 & 17 & 20 & 21 & 22 & 23 & 24 & 25 \\
\hline$\%$ & 43.1 & 53.1 & 13.5 & 83.4 & 76.9 & 13.6 & 29.7 & 30.4 & 52.9 & 28.3 & 65.4 \\
\hline $\begin{array}{c}\text { Sample } \\
\text { no }\end{array}$ & 26 & 30 & 31 & 32 & 33 & 34 & 35 & 36 & 37 & 38 & 39 \\
\hline $0 \%$ & 39.4 & 12.9 & 15.2 & 10.9 & 21.8 & 10.7 & 26.4 & 62.6 & 32.3 & 17.9 & 34.7 \\
\hline
\end{tabular}




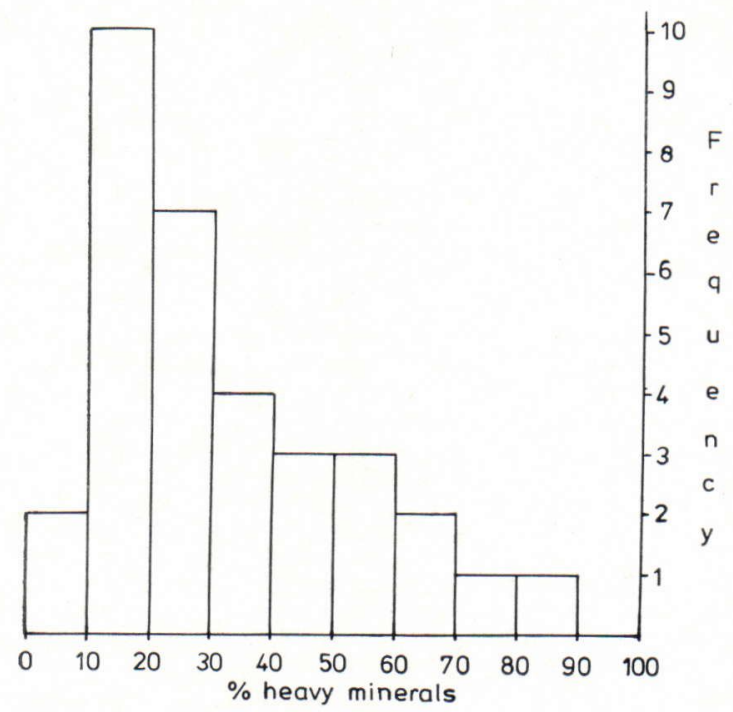

Fig. 4. Frequency distribution of the total amount of heavy minerals (including magnetite).

shore topography, difference in lake size or the nature of the local bedrock. In order to study the effect of lake size, total percentages of heavy minerals were plotted against lake size measured as the maximum free waterway leading to the sampling site (Fig. 5). It is seen that these two variables have no correlation at all. One would think that the larger the lake the more energetic would be the sedimentary environment. However, if the percentage of the heavy minerals is dependant on energy factors, the size of the lake does not seem to reflect this. Differences in percentage values are therefore to be explained on the basis of differences in local topography which lead to differences in energy at the sampling sites independent of lake size or on the basis of differences in the nature of the local bedrock. In order to evaluate the effect of the local bedrock a comparison was made on the basis of the general geological data presented in Table 1, and the total heavy mineral percentages in Table 3. This shows, that both high (nos. 1, 13, and 14) and low (12 and 15) values can be found for samples

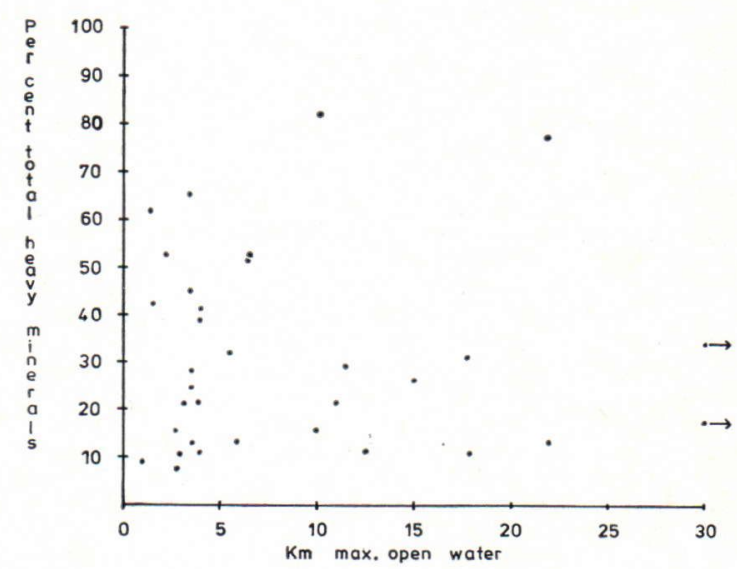

Fig. 5. Dependence of the total amount of heavy minerals on waterway size.

representing the Karelidic schist areas, for the Prekarelian basement gneiss areas (high 3,8 and 36; low 2, 5, 6, and 7) and for the areas of Karelian orogenic granites (high 16 and 17; low 20). The nature of the bedrock therefore does not seem to be of importance as far as the total amount of heavy minerals is concerned. The possibility remains that the decisive factor is a local topographic feature such as the steepness of the shore which, independent of lake size, renders the process more efficient at sites where steepness is pronounced and leaves flat shores more or less unaffected.

\section{Heavy mineral composition}

Table 4 shows the results of the heavy mineral determinations, with the magnetite content being shown separately in Table 5 as a percentage by weight of the total heavy mineral fraction. The percentages of each of the minerals in Table 4 refer to the number of grains in the non-magnetic heavy fraction. The amphiboles are, with the exception of 
Table 4. Heavy mineral composition of the non-magnetic fraction of lake shore placer sands in northern Finland. For sampling sites see Table 1 and Fig. 1. The values are given as percentages of the number of grains recorded.

\begin{tabular}{|c|c|c|c|c|c|c|c|c|c|c|c|c|}
\hline $\begin{array}{l}\text { Sample } \\
\text { no }\end{array}$ & $\begin{array}{c}\text { Amphi- } \\
\text { bole }\end{array}$ & $\begin{array}{l}\text { Epi- } \\
\text { dote }\end{array}$ & $\begin{array}{c}\text { Opaque } \\
\text { minerals }\end{array}$ & $\begin{array}{c}\text { Gar- } \\
\text { net }\end{array}$ & $\begin{array}{l}\text { Pyro- } \\
\text { xene }\end{array}$ & Rutile & $\begin{array}{l}\text { Tita- } \\
\text { nite }\end{array}$ & $\begin{array}{l}\text { Zir- } \\
\text { con }\end{array}$ & $\begin{array}{l}\text { Stau- } \\
\text { rolite }\end{array}$ & $\begin{array}{c}\text { Apa- } \\
\text { tite }\end{array}$ & $\begin{array}{l}\text { Oli- } \\
\text { vine }\end{array}$ & Others \\
\hline 1 & 60 & 9 & 8 & 8 & 4 & 2 & 2 & 2 & 1 & 1 & 2 & 1 \\
\hline 2 & 68 & 6 & 9 & 3 & 1 & 1 & 1 & 7 & 1 & 1 & - & 2 \\
\hline 3 & 40 & 10 & 35 & 6 & 4 & 1 & 1 & 2 & - & 1 & - & - \\
\hline 4 & 65 & 8 & 6 & 3 & 5 & - & 1 & 6 & 1 & 1 & 2 & 2 \\
\hline 5 & 59 & 23 & 1 & 1 & 2 & 1 & 5 & 6 & - & - & - & 2 \\
\hline 6 & 71 & 13 & 3 & 1 & 4 & - & 3 & 2 & - & - & 2 & 1 \\
\hline 7 & 60 & 12 & 5 & 2 & 9 & 1 & 3 & 3 & 1 & 1 & 1 & 2 \\
\hline 8 & 52 & 4 & 22 & 4 & 5 & - & 1 & 7 & - & 2 & 2 & 1 \\
\hline 9 & 79 & 5 & 5 & 2 & 2 & - & 2 & 1 & 1 & 2 & 1 & - \\
\hline 11 & 66 & 5 & 13 & 4 & 4 & 1 & 2 & 1 & 1 & 1 & 2 & - \\
\hline 12 & 80 & 5 & 4 & 4 & 1 & - & 1 & - & - & - & 1 & 3 \\
\hline 13 & 52 & 4 & 30 & 5 & 2 & 1 & 2 & 3 & 1 & - & - & - \\
\hline 14 & 71 & 6 & 8 & 2 & 5 & 1 & 2 & 2 & 2 & - & - & 1 \\
\hline 15 & 69 & 4 & 10 & 2 & 6 & 1 & 1 & 3 & 2 & - & 1 & 1 \\
\hline 16 & 43 & 2 & 44 & 3 & 4 & 1 & 2 & 1 & - & - & - & - \\
\hline 17 & 43 & 8 & 34 & 4 & 4 & 1 & 2 & 1 & 2 & - & 1 & - \\
\hline 20 & 70 & 9 & 10 & 1 & 7 & - & 2 & 1 & - & - & - & - \\
\hline 21 & 51 & 9 & 10 & 3 & 6 & - & 4 & 1 & - & 2 & - & $14^{1}$ \\
\hline 22 & 82 & 2 & 4 & 2 & 6 & - & - & 1 & - & 2 & - & 1 \\
\hline 23 & 89 & 2 & 2 & 2 & 4 & - & - & - & - & 1 & - & - \\
\hline 24 & 68 & 9 & 8 & 4 & 6 & 1 & - & 2 & - & 1 & 1 & - \\
\hline 25 & 62 & 4 & 15 & 2 & 3 & - & 2 & 2 & 1 & 7 & 1 & 1 \\
\hline 26 & 81 & 4 & 4 & 2 & 3 & - & 1 & 1 & 1 & 2 & 1 & - \\
\hline 30 & 71 & 7 & 3 & 6 & 3 & - & 3 & 2 & - & 4 & - & 1 \\
\hline 31 & 48 & 7 & 22 & 10 & 3 & - & 3 & 5 & - & 1 & 1 & - \\
\hline 32 & 75 & 8 & 1 & 1 & 3 & - & 2 & 5 & - & 1 & 3 & 1 \\
\hline 33 & 76 & 4 & 4 & 2 & 5 & - & 1 & 6 & 1 & - & 1 & - \\
\hline 34 & 75 & 7 & 10 & 2 & 2 & - & 2 & 1 & - & - & - & 1 \\
\hline 35 & 74 & 8 & 7 & 3 & 3 & - & - & 3 & 1 & 1 & - & - \\
\hline 36 & 37 & 12 & 32 & 5 & 5 & 1 & 2 & 5 & 1 & - & - & - \\
\hline 37 & 51 & 5 & 31 & 2 & 3 & 2 & 1 & 3 & - & 1 & - & 1 \\
\hline 38 & 65 & 11 & 5 & 7 & 4 & 1 & 1 & 3 & 1 & 1 & 1 & - \\
\hline 39 & 56 & 9 & 11 & 8 & 3 & 1 & 4 & 6 & - & 1 & 1 & - \\
\hline Range & $37-89$ & $2-23$ & $1-44$ & $1-10$ & $1-9$ & $0-2$ & $0-5$ & $0-7$ & $0-2$ & $0-7$ & $0-3$ & $0-14$ \\
\hline Mean & 63.90 & 7.30 & 12.60 & 3.52 & 3.97 & 0.55 & 1.78 & 2.85 & 0.61 & 1.06 & 0.76 & 1.09 \\
\hline st.dev & 13.28 & 4.08 & 11.67 & 2.26 & 1.74 & 0.62 & 1.19 & 2.09 & 0.66 & 1.39 & 0.83 & 2.45 \\
\hline
\end{tabular}

1 goethite

two extreme cases where magnetite is very abundant, by far the most abundant minerals in the samples. Amphiboles of various kinds (tremolite, common hornblende, cummingtonite and antophyllite) were grouped together during the grain counting because of the impossibility of distinguishing some of them purely on the basis of their optical properties, and because of the rareness of others. In the two exceptional cases where magnetite is more abundant than amphiboles the total amount of heavy minerals is also very high. These exceptions are discussed in more detail on page 40. A general comparison with previously published material shows that the mineral phases are the same as those in the material studied by Braithwaite and Javad Ali (1978) from Scotland, by Da Silva (1979) from Brazil and by $\mathrm{Pe}$ and Panagos (1979) from Greece. In the material studied by 
Table 5. Amount of magnetite calculated as a percentage by weight of the total heavy fraction including magnetite. For sampling sites see Table 1.

\begin{tabular}{|c|c|c|c|c|c|c|c|c|c|c|c|}
\hline $\begin{array}{c}\text { Sample } \\
\text { no }\end{array}$ & 1 & 2 & 3 & 4 & 5 & 6 & 7 & 8 & 9 & 11 & 12 \\
\hline$\%$ & 0.8 & 0.4 & 0.3 & 0.2 & 0.0 & 0.1 & 0.1 & 3.3 & 0.1 & 2.6 & 0.1 \\
\hline $\begin{array}{c}\text { Sample } \\
\text { no }\end{array}$ & 13 & 14 & 15 & 16 & 17 & 20 & 21 & 22 & 23 & 24 & 25 \\
\hline$\%$ & 0.1 & 1.8 & 0.4 & 55.5 & 43.8 & 10.6 & 1.9 & 0.6 & 0.1 & 6.6 & 15.5 \\
\hline $\begin{array}{c}\text { Sample } \\
\text { no }\end{array}$ & 26 & 30 & 31 & 32 & 33 & 34 & 35 & 36 & 37 & 38 & 39 \\
\hline $0 \%$ & 0.7 & 1.3 & 3.0 & 0.5 & 1.8 & 7.5 & 0.3 & 1.9 & 28.9 & 3.7 & 10.4 \\
\hline
\end{tabular}

Granath (1978) from Sweden magnetite, the non-magnetic opaque minerals and garnet are more common than in the amphibolepredominating samples of the present study.

The lack of biotite is noteworthy. Biotite could, on the basis of its density (2.9-3.3; Tröger 1971), and its high position in the »order of persistence» sequence of Pettijohn (1941), be present among the heavy minerals, as has also been noted by Hails (1976, p. 237). Notwithstanding it was only recorded in a few rare cases where its presence was obviously due to the richness of inclusions, mainly zircon. The form of the biotite grains obviously helps the flakes to float better than grains of other minerals of comparable density and size. In addition, the low hardness of the mineral and its perfect cleavage accentuate the small size of its grains which are, therefore, not in hydro-dynamic equilibrium with the larger grains of other minerals of comparable density.

In addition to the minerals listed in the tables sporadic grains of a few other phases were noted. The content of these minerals never rose high enough to be recorded in the percentage countings. Among these occasional minerals tourmaline, chlorite, feldspars with heavy mineral inclusions, sillimanite, kyanite, ilmenorutile, olivine, gold, topaz and monazite may be mentioned.

A mphiboles

As stated previously, all the different kinds of amphiboles were recorded as a single group. In comparison with the common green hornblende other amphiboles were subordinate and a further distinction was considered meaningless.

Under the stereo-microscope amphiboles were identified as black, dark green, brownish-green, bluish-green and light green, often elongated, more or less cylindrical grains in which the cleavage planes were in most of the cases detectable as brilliant smooth surfaces.

The lowest value recorded for the amphiboles is $37 \%$ of the grains of the non-magnetic heavy mineral fraction. The arithmetic mean is 63.90 and the highest value 89 per cent. The frequency distribution of the am- 


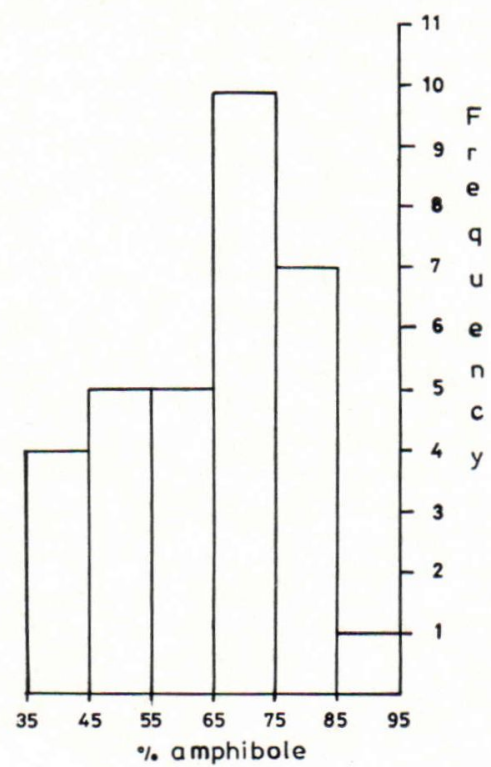

Fig. 6. Frequency distribution of amphibole.

phiboles in classes with a 10 per cent interval is depicted in Fig. 6. The diagram shows that samples with 65 to 85 per cent amphibole are the most common. The high arithmetic mean and the relatively narrow standard deviation (13.28) imply that amphiboles are, as a rule, present in large quantities. Assuming a normal distribution, two thirds of the cases fall between 50 and 77 per cent amphibole.

\section{M a g n e tite}

As previously stated, magnetite was calculated as a percentage of the sum of magnetite plus non-magnetic heavy minerals. The results with the frequency distribution of magnetite are shown in Table 5 and Fig. 7. Contrary to common belief, the content of magnetite is relatively low although there is a large scatter in the values. At one extreme magnetite is totally or practically absent while, at the other, some samples contain as much as 40 to 50 per cent magnetite. Most frequent, however, is a figure between 0.1 and 0.8 per cent (Table 5 ).

In order to study the possible causes of the variation in the amount of magnetite its values were plotted relative to the total amount of heavy minerals (Fig. 8). As a working hypothesis one could suppose that the amount of magnetite would increase as the total amount of heavy minerals increases, reflecting the general enrichment of heavy minerals as the light minerals are more effectively removed during the prolonged action of the enriching process. However, Fig. 8 shows that the correlation is very weak and the scatter of the points conspicuous. Magnetite can be seen to possess both low and relatively high values independent of the total amount of heavy minerals. For up to 60

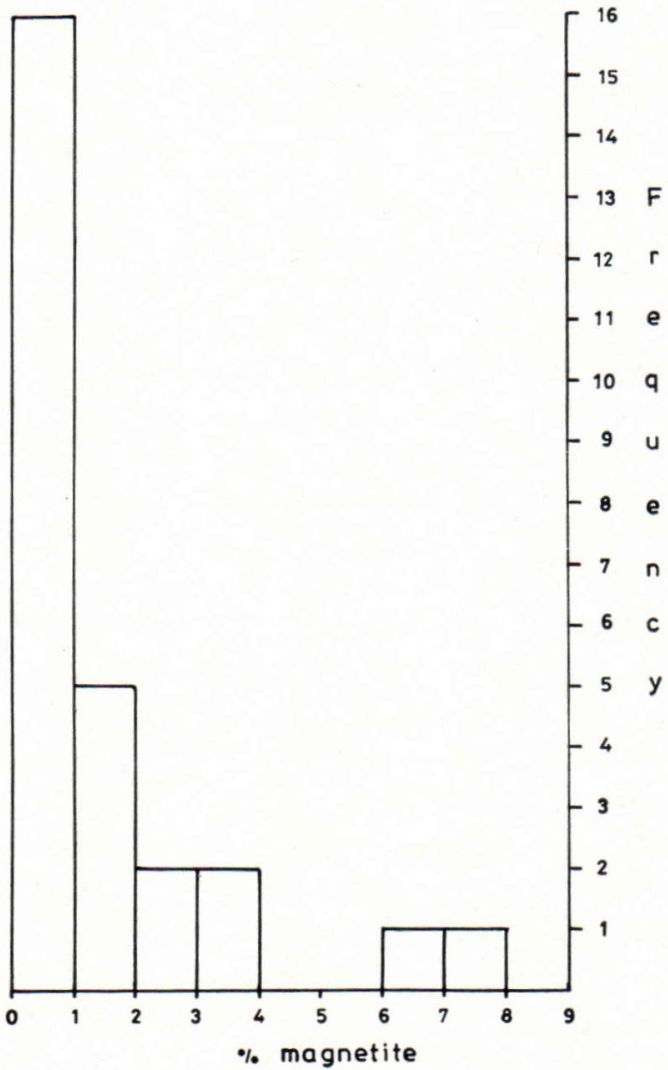

Fig. 7. Frequency distribution of magnetite in percentage classes below 9 percent. 


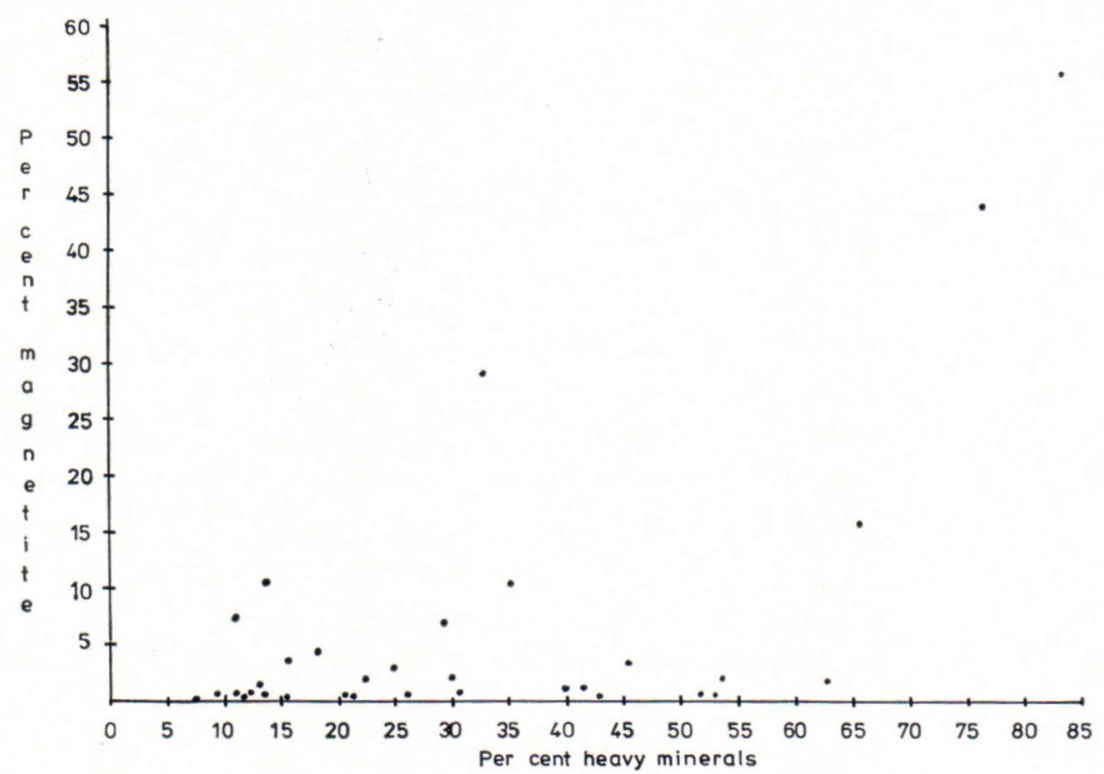

Fig. 8. Relationship of the amount of magnetite to the total amount of magnetic and non-magnetic heavy minerals. per cent heavy minerals the amount of magnetite varies considerably from very low to as high as about 30 per cent. A weak trend towards the simultaneous increase of magnetite and the total amount of heavy minerals is visible in the right hand side of the diagram, but the trend is very weak and the values for magnetite are so low, that one can say that an enrichment of magnetite is by no means an integral feature of general enrichment of heavy minerals. The amount of magnetite, therefore, seems to be more dependent on some other factor. This factor is obviously the original composition of the sediment, which in turn might reflect the general nature of the bedrock of the area. On the basis of the data in Tables 2 and 5 it is apparent, perhaps surprisingly, that the high figures of magnetite are characteristic of samples 16,17 and 37 all of which represent sites on the large orogenic granites of Central Lapland specifically in the Kemijärvi area. The value for sample 20 is also relatively high and this likewise represents an area of the Karelian orogenic granites of Central Lapland but at lake Miekojärvi. The high magnetite figure may be a reflection of the iron-ore deposits of the nearby Misi area (Nuutilainen 1968) or the rarity of amphiboles in the granites. Low magnetite values are, on the other hand, characteristic for sites in the Karelian schist belts and Archean greenstone belts and for areas of Prekarelian basement gneiss complex (samples 1 and 2 from the Karelian Puolanka schist belt, nos. 3 and 4 from the Archean Kuhmo greenstone belt, nos. 12 and 13 from the Karelian Kuusamo schist belt, no. 15 from the Salla greenstone area and nos. 5-7 from the basement complex).

In conclusion it is suggested that the amount of magnetite is dependent on the general nature of the bedrock at the sampling site, being abundant in the areas of orogenic Karelian granite massifs and low in the schist areas and the basement complex areas.

Opaque minerals

The opaque minerals, other than magnetite, were recorded as single group during grain counting under the polarizing microscope (Table 4), but when counting in reflected light 
Table 6. Relative amounts of ilmenite and hematite among the opaque minerals of the non-magnetic heavy fraction. The figures are percentages based on numbers of grains. For sampling sites see Table 1.

\begin{tabular}{|c|c|c|c|c|c|c|c|c|c|c|c|c|}
\hline $\begin{array}{c}\text { Sample } \\
\text { no }\end{array}$ & 1 & 2 & 3 & & 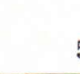 & 6 & & & 8 & 9 & 11 & 12 \\
\hline Ilmenite & 80.5 & 90.1 & 65. & & & 57 & & & 69.1 & 75.8 & 56.7 & 64.1 \\
\hline \multirow[t]{4}{*}{ Hematite } & 19.5 & 9.9 & 34 & & 23 & 42 & & & 30.9 & 24.2 & 43.3 & 35.9 \\
\hline & & \multicolumn{2}{|c|}{$\begin{array}{c}\text { Sample } \\
\text { no }\end{array}$} & 13 & 14 & 15 & 16 & \multicolumn{2}{|c|}{17} & & & \\
\hline & & \multicolumn{2}{|c|}{ Ilmenite } & 67.7 & 53.3 & 63.5 & 42.2 & 46.3 & & & & \\
\hline & & \multicolumn{2}{|c|}{ Hematite } & 32.3 & 46.7 & 36.5 & 57.8 & 53.7 & & & & \\
\hline
\end{tabular}

under the ore microscope the two main phases of the material, ilmenite and hematite, were recorded separately. The relative amounts of grains of these two minerals are given in Table 6 .

The total amount of opaque minerals (see Table 4) in the non-magnetic heavy fractions of the samples varies from 1 to 44 per cent, the percentage rising as that of the amphiboles decreases. In order to illustrate the relationship between the amount of opaque minerals and amphiboles the two are plotted against each other in Figs. 9 and 10. It is seen that the percentage of amphiboles can vary between 60 and 90 while the amount of the opaque minerals stays below and around 10 per cent. However, when the amount of amphiboles falls below 60, the percentage of the opaque minerals starts rising from 10 to as high as 40 or 50 . This negative correlation of the opaque and the amphiboles may result from the arithmetical properties of the variables of a fixed sum (see Chayes 1962) but geologically and in reality it points to the fact that, whatever the process or condition that leads towards the impoverishment of amphiboles, the result is a material rich in opaque minerals. The density of the amphiboles being lower than those of the opaque minerals a prolonged enriching effect of waves can be thought to lead towards the above result.

In addition to ilmenite and hematite small amounts of opaque rutile, ilmenorutile, leucoxene, pyrite, chalcopyrite and gold were encountered. The amounts of these minerals were, however, so small that they were not included in the grain counting results in Table 6 .

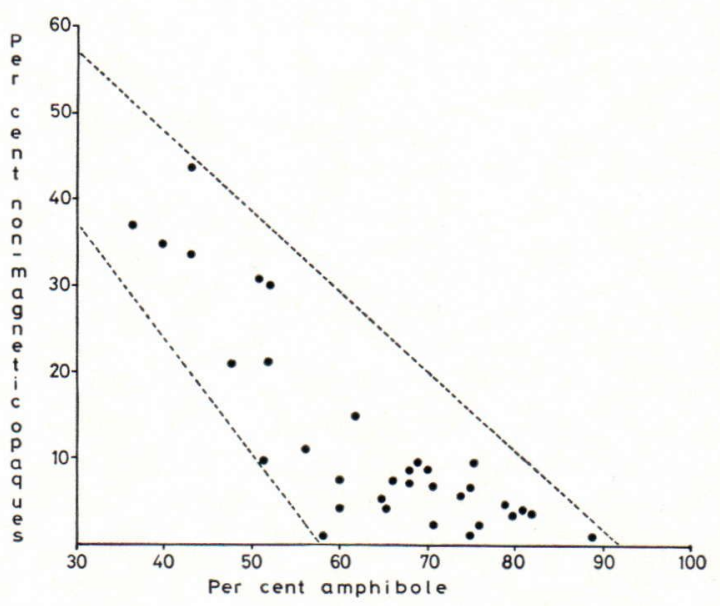

Fig. 9. Percentages of amphibole and nonmagnetic opaque minerals plotted against each other. 


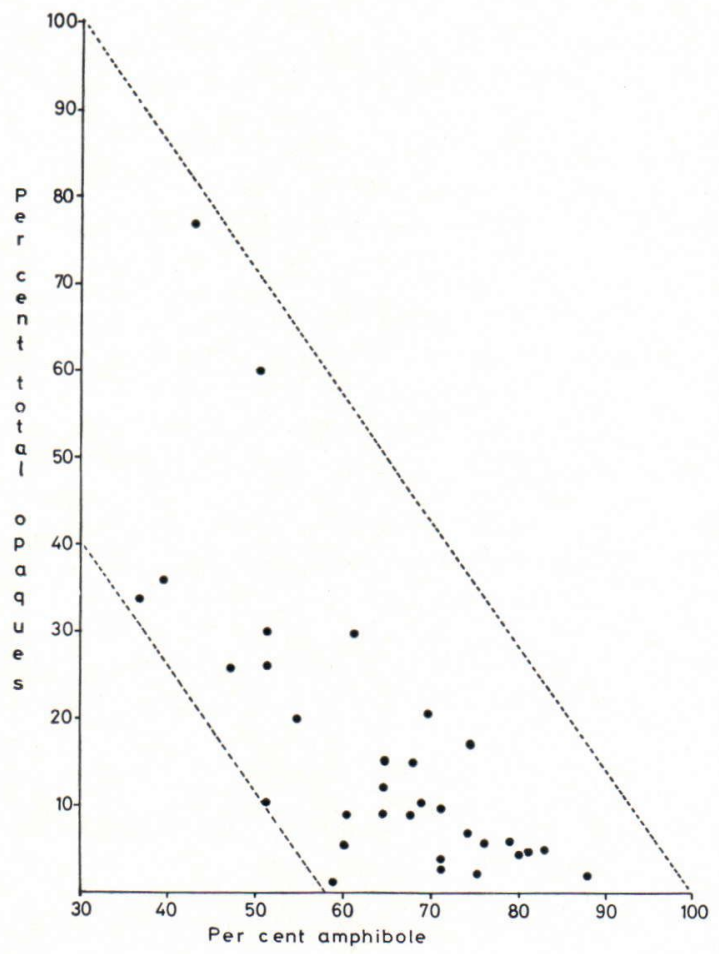

Fig. 10. Amount of amphibole relative to the total amount of the opaque minerals.

E p idote

After amphiboles and opaque minerals epidote is the most common single mineral in the material studied. Its abundance (see Table 4) varies from 2 to 23 per cent of the non-magnetic heavy fraction. Under the stereo-microscope epidote is seen in the loose material as yellow or yellow-green translucent or transparent grains which sometimes show elongation along the crystallographic b-axis but mostly lack elongation as the grains are worn and rounded. Under the polarizing microscope the mineral is identified on the basis of its yellowish, sometimes pleochroic colour and the large axial angle as well as the abnormal interference colours.

Fig. 11 shows the frequency distribution of epidote in the non-magnetic heavy fraction. It is readily apparent, as the rather small standard deviation (4.08, Table 4) also indicates, that epidote is fairly uniformly present in percentages ranging from 0.5 to 12.5 but rare at values above 12.5 per cent. The arithmetical mean is 7.3 per cent and the most frequent values between 6.5 and 8.5 per cent. An exceptionally high value for epidote $(23 \%)$ is recorded in sample no. 5 which is from Lake Valkeinen, south of Kuusamo. The high value is obviously a result of the commonness of epidote in the bedrock of large areas of the Presvecokarelian basement gneiss complex of the area (Matisto 1958), the dominant rock in this complex being an oligoclaseepidote gneiss (Matisto, op. cit.). The same is also true for the rest of the samples from the neighbouring basement gneiss areas, samples 3,6 and 7 , even though the percentages are not quite as high as in the case of sample no. 5. A similar dependence of the abundance of epidote on the nature of the local bedrock has been noted by Callahan (1979) among the heavy minerals of stream sediments in Labrador.

Exceptional features in the heavy mineral compositions

Normal, and frequently occurring, figures for the percentage of amphiboles in the placer sands of the present study concentrate around 65 to 75 per cent of the non-magnetic heavy fraction. Exceptionally high figures are encountered in a few cases and in these the percentage rises to about 90 . This seems to be true particularly for the samples from the

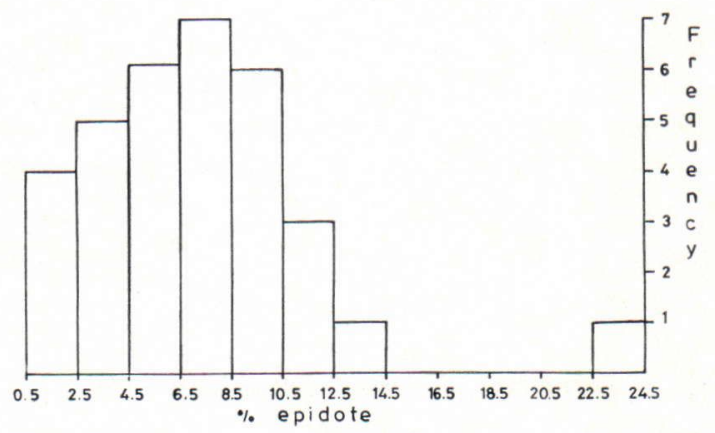

Fig. 11. Frequency distribution of the percentage of epidote in the non-magnetic heavy fraction. 
northernmost sampling sites, those of lake Ounasjärvi and Muotkajärvi in northwestern Lapland. The samples from Kangosjärvi in Muonio and Penämö in Ranua also show high figures; 86 and 80 respectively, while at the same time the percentages of the opaque minerals $(5,0,5$ and 5 respectively) are exceptionally low. The reason for these deviations from the norm may lie in the composition of the local bedrock, amphibole being abundant for instance in the albite diabases of the Enontekiö area (Meriläinen 1961) and in the amphibolites of the Muonio area. Conversely, exceptionally low percentages of amphiboles are recorded where the opaque mineral content is high. For instance, the samples from lake Oulujärvi (31, Table 4), Hossajärvi (36) and Kemijärvi (16 and 17) show exceptionally low values (45, 35, 46 and 30 ) for amphiboles and high values for the opaque minerals $(25,36,42$ and 30$)$. This is obviously due to two factors. The rise in opaque minerals is considered the primary factor being the result of the high-energy environment as discussed on p. 41. A second factor is probably the special nature of the bedrock which in these areas is poorer in amphiboles than elsewhere.

Exceptionally high values for epidote have already been reported and discussed (p. 42).

Among the less frequent minerals attention is drawn to the sporadic abundance of apatite (no. 25, Table 4) and goethite (no. 21, Table 4). The high figure for apatite $(8 \%)$ has no obvious reason as far as the composition of the local bedrock in the light of available data is concerned whereas the unique abundance of goethite $(13 \%)$ in the sample from Lake IsoVietonen is obviously a result of the occurrence of bog-iron deposits at the bottom of the lake.

\section{Mineral composition and the local bedrock}

At first glance the local bedrock seems to have no apparent effect on the main features of the mineral composition of the samples studied. The mineral composition shows high percentages of amphiboles in most of the cases despite the variation of local bedrock. The homogeneity of the mineral composition of the samples with respect to the chief minerals is, in most cases, a result of the complex history of the original sediments from which the placer enrichments are formed. The acmumulations are formed primarily by the differentiating action of waves working on the sands, silts or tills of the area. These surfacial deposits of northern Finland are of glacial origin and are thus a mixture of material derived from large areas. Consequently, only very large areas of homogeneous bedrock characterized by conspicuous mineralogical similarity or by mineralogical specialty can be reflected in the mineral composition of the placer sands, as Abdalla and Whyte (1979) have also noted. The special cases in this study are, the epidote-rich basement gneisses in the eastern part of northern Finland and, on the basis of tentative microscopic observations, the garnet-rich rocks of the granulite-arc of northern Lapland (see Simonen 1980). The lack or scarcity of amphiboles and the simultaneous richness of magnetite and other opaque minerals may also be, at least partially, a result of the special nature of the bedrock in certain cases as discussed on page 40 .

\section{Summary and conclusions}

The present study of samples of black sands from lake shores in northern Finland shows that the total amount of heavy minerals in them varies considerably. The total amount of heavy minerals in the sampled $2 \mathrm{~mm}$ thick layers varies from 7.2 to 89.0 per cent by weight of the total mass of the sample. The amount is supposed to be dependent on local topography, particularly the steepness of the shore, the steepest shores leading to a high- 
energy sedimentary environment and an effective removal of the light minerals. The size of the lake does not seem to have any significance in this connection. Among the heavy $(\mathrm{d}>2.89)$ minerals the amphiboles are almost without exception the most abundant. Their amount varies from 37 to 89 per cent of the total grains of the non-magnetic heavy fraction, the average being $63.9 \%$. Magnetite alone, in some rare cases, exceeds the amount of amphiboles. In rare, very high energy cases, where the removal of even the amphiboles has obviously taken place, the amount of magnetite may rise to as much as 50 per cent by weight of the total sample. The nature of the bedrock is also of importance in that connection. The highest amounts of magnetite are recorded for samples from sites where orogenic Karelian granites are extensive. Here the amphibole content of the rock is low and the high amount of magnetite in the placer sands is a reflection of this deficiency. The high magnetite percentage may also, in some cases, be a result of the occurrence of iron-ore deposits in the bedrock.

In addition to magnetite non-magnetic opaque minerals are abundant. Their combined amount varies from 1 to 44 per cent of the non-magnetic heavy grains with a mean value of 12.6 per cent. Among the nonmagnetic opaque minerals ilmenite and hematite are the most abundant minerals. Among the transparent heavy minerals epidote, pyroxenes, garnet, zircon, titanite and locally also apatite are the most frequent after the amphiboles.

The nature of the local bedrock is not, as a general rule, reflected in the main mineral composition of the placer sands since amphiboles are uniformly dominant. Locally, however, high amounts of epidote, apatite and magnetite, and tentatively garnet for the granulites, are present because of the special nature of the underlying bedrock.

From the point of view of a bedrock geologist the counterpart of the sedimentary process which operates on modern lake shore may have produced some para-amphibolites which occur in the bedrock as intercalations among the arenaceous sediments. Considering the commonness of amphiboles and only exceptional richness of magnetite in the placer sands, to invoke this process as an explanation for the origin of some of the iron-formations is valid only in very specific cases.

Acknowledgements - The present study was made possible through a grant awarded by the Natural Science Board of the Finnish Academy. The author's indebtness for this financial support is gratefully acnowledged. Mrs. Sheila Hicks, Ph.D., kindly corrected the English of the manuscript and deserves my warmest thanks. In the laboratory I was assisted by Messrs. Risto Nikula, Pekka Tuisku and Erkki Vanhanen to all of whom I would like to express my gratitude. Last but not least, my son Kari, helped me indefatigably during the field work. It is to him that I would like to express my special gratitude.

\section{References}

Abdalla, A. Y. and Whyte, F. (1979) The influence of bedrock on heavy mineral content of streams within glaciated area of Pertshire. Scott. J. Geol. 15 (2), 129-138.

Allen, V. T. (1948) Weathering and heavy minerals. J. Sediment. Petr. 18, 38-42.

Baker, G. (1945) Heavy black sands on some Victorian beaches. J. Sediment. Petr. 15, 11-19.

- (1962) Detrital heavy minerals in natural ac- cumulates. Austr. Inst. Min. Met. Monogr. Ser. 1. $146 \mathrm{pp}$.

Bayrock, C. A. (1962) Heavy minerals in till central of Alberta. J. Alberta Soc. Petroleum Geol. 10, 171-184.

Beasley, A. W. (1948) Heavy-mineral beach sands of southern Queensland, 1. Proc. R. Soc. Queensland, 59, 109-140.

- (1950) Heavy-mineral beach sands of southern 
Queensland, 2., Proc. R. Soc. Queensland 61, 59-104.

Braithwaite, C. J. R. and Jaead Ali, A. (1978) Heavy mineral distribution in the Old Red Sandstone of the North-Eastern Midlang Valley of Scotland. Scott. J. Geol. 14 (4), 273-288.

Callahan, J. E. (1980) Heavy minerals in stream sediments from Churchill Falls, Labrador an aid in bedrock mapping. Can. J. Earth Sci., 17, 244-253.

Carver, R. E., (ed.) (1971) Procedures in Sedimentary Petrology. Wiley, New York. $635 \mathrm{pp}$.

Chayes, F. (1962) Numerical correlation and petrographic variation. J. Geol. 70, 440-452.

Cobb, E. M. (1973) Placer deposits of Alaska. U.S. Geol. Survey Bull. 1374. 200 pp.

Connah, T. M. (1962) Beach sand heavy mineral deposits of Queensland. Queensland Dep. Mines. Publ., 302. 32 pp.

Da Silva, M. A. M. (1979) Provenance of heavy minerals in beach sands, southeastern Brazil: from Rio Grande to Chui (Rio Grande do Sul State). Sediment. Geol. 24, 133-149.

Dryden, A. L. and Dryden, C. (1946) Comparative rates of weathering of some common heavy minerals. J. Sed. Petr. 16, 91-6.

Dubois, R. N. (1972) Inverse relation between foreshore slope and mean grain-size as a function of the heavy mineral content. Geol. Soc. Am. Bull. 83, 871-876.

Gardner, D. E. (1955) Beach sand heavy minerals deposits of Eastern Australia. Bur. Miner. Res. Austr. Bull., 28, 1-103.

Granath, G. (1978) Heavy minerals from placer deposits in the county of Norrbotten, northern Sweden, and their provenance. Bull. Geol. Inst., Uppsala, 7, 111-175.

Griffith, S. V. (1960) Alluvial prospecting and mining $245 \mathrm{pp}$.

Hails, J. R. (1976) Placer Deposits in Wolf, K. H. (ed.) Handbook of strata-bound and stratiform ore deposits. Vol. 3, pp. 213-244. Elsevier, Amsterdam.

Hilmy, M. E. (1951) Beach sands of the Mediterranean Coast of Egypt. J. Sed. Petr. 21, 109120.

Hosking, K. F. G. and Ong, P. M. (1964) The distribution of tin and certain other heavy metals in the superficial portions of the Gwythean/ Hayle beach of West Cornwall. Trans. R. Geol. Soc. Cornwall 19 (5), 352-390.
Hutton, C. O. (1950) Studies of heavy detrital minerals. Geol. Soc. Am. Bull. 61, 635-710.

Martens, J. H. C. (1928) Beach deposits of ilmenite, zircon and rutile in Florida. Geol. Survey Fla., Ann. Rep. 19, 124-154.

Matisto, A. (1958) Suomen geologinen yleiskartta. The General Geological Map of Finland. LehtiSheet D5, Suomussalmi. Kivilajikartan selitys. Explanation to the Map of Rocks. With an English Summary. Geologinen Tutkimuslaitos. Geological Survey of Finland. 115 pp.

Meriläinen, $K$. (1961) Albite diabases and albitites in Enontekiö and Kittilä, Finland. Bull. Comm. Geol. Finlande 195. 75 pp.

Moreland, G. C. (1968) Preparation of polished thin sections. Am. Min., 50, 2070-2074.

Nuutilainen, J. (1968) On the geology of the Misi iron ore province, northern Finland. Ann. Acad. Scient. Fennicae, Ser. A., III, no 96. 98 pp.

Pardee, J. T. (1934) Beach placers of the Oregon coast. U.S. Geol. Surv. Cinc., 8. 41 pp.

Pe, G. G. and Panagos, A. G. (1979) Heavy mineralogy of river and beach sands, continental Greece. N. Jb. Miner. Abh., 136, 254-261.

Pettijohn, F. T. (1941) Persistence of heavy minerals and geologic age. J. Geol., 49, 610-625.

- (1975) Sedimentary Rocks. 3rd edition. Harper \& Row, New York. 628 pp.

Pirkle, E. C. and Yoho, W. M. (1970) The heavy mineral ore body of Trail Ridge, Florida, Econ. Geol. 65, 17-30.

Ras, C. B. (1957) Beach erosion and concentration of heavy mineral sands. J. Sed. Petr. 27, 143-7.

Reittenhouse, G. (1943) The transportation and deposition of heavy minerals. Bull. Geol. Soc. Am., 54,

Schott, W. (1976) Mineral (inorogenic) resources of the oceans and ocean floors: a general review, pp. 245-294. in Wolf, K. E. H., (ed.), Handbook of and stratiform ore Deposits. Elsevier. Amsterdam.

Seibold, E. (1974) Der Meeresboden. Ergebnisse und Probleme der Meeresgeologie. Springer. New York. 183 pp.

Simonen, A. (1980) Suomen kallioperä, Prequaternary rocks of Finland, $1: 1.000 .000$.

Tröger, W. E. (1971) Optische Bestimmung der Gesteinsbildenden Minerale. Teil 1. Bestimmungstabellen. E, Schweizerbarstsche Verlagsbuchhandlung. Stuttgart. $188 \mathrm{pp}$.

Manuscript received, November 13, 1980 